\title{
Tenth IAU General Conference, New Delhi, 6-9 February 1995
}

The Tenth General Conference of IAU will take place at New Delhi, from 6 to 9 February 1995, and will be hosted by fawaharlal Nehru University, together with the Indian Association of Universities and with the support of the Universities Grants Commission. It will be invited to consider the following general theme: Global Civilization and Cultural Roots: Bridging the Gap - The Place of International University Cooperation. Preliminary information on the Conference Programme has been sent out to universities worldwide and major international and national bodies concerned with higher education.

\section{THEME}

\section{Global Civilization and Cultural Roots: Bridging the Gap - The Place of International University Cooperation}

Among the major contradictions shaping the events of the world today are trends and concepts of globalization, integration and convergence, on the one hand, and of national and cultural redefinition, fragmentation and disaggregation, on the other. Against this background, universities are called upon to define joint responsibilities and responses in assuming their proper place and role vis-à-vis the challenges of the 21 st Century. The Conference will allow leaders in higher education world-wide to examine the substantive implications these developments pose for setting the agenda for international university cooperation.

The interdependence of technological, economic and financial systems on a world scale is a recurrent refrain in contemporary debate. Are economics, technology and market forces enough to hold a world order together in an age of mass communication? Are cultural diversity and historic belief systems compatible with technological integration? Against the emergence of a 'world system' stands an equally powerful tendency towards fragmentation and disaggregation in the cultural domain and most particularly in the area of group self-definition, both within and between nations. The task of constructing societies able in a coherent manner to deal with these tensions is one of the most important challenges the 21 st Century will face.

In the cross-play of technical and economic integration and cultural diversity, the university occupies a key position. It is seen as an instrument for advancing the former. Historically, it has served to define the latter. The university is then at the balance point between these two potentially conflicting developments. How have they borne down upon the university? How is the university meeting these contradictory forces? What is the part international cooperation may play in reconciling them? How may the university fulfil its prime task of advancing scholarship whilst upholding basic humanitarian values? These are some of the substantive elements of the agenda for collaboration on which university leaders will be called to exchange views, to define action for the universities and to set the role the International Association of Universities may fulfil in this undertaking. 